\title{
Kimura Disease with Parotid Swelling and Cervical Lymphadenopathy: A Case Report and Literature Review
}

\author{
Parotid ve Servikal Lenfadenopatili Kimura Hastalığı: \\ Bir Olgu Sunumu ve Literatür Taraması
}

\section{Sha Kri EH DAM๑, Sakinah MOHAMAD $\odot$, Irfan MOHAMAD $\odot$}

Ethics Committee Approval: Not Applicable.

Conflict of Interest: The authors declare that they have no conflict of interest.

Funding: None.

Informed Consent: Informed consent was taken.
Cite as: Eh Dam VSK, Mohamad S, Mohamad I. Kimura disease with parotid swelling and cervical lymphadenopathy: A case report and literature review. Medeniyet Med J. 2020;35:170-4.

\begin{abstract}
Kimura disease $(K D)$ is a rare chronic benign inflammatory disorder of unknown etiology that is prevalent in Asian males. The head and neck region, especially the parotid glands and cervical lymph nodes, are most commonly affected. Diagnosis is based on clinicopathological features, while radiology findings are nonspecific. Although various treatment strategies have been proposed, there is a high recurrence rate. Combination therapy has been found to produce better results than monotherapy. We present a case of $K D$ with huge parotid and cervical lymph node involvement that was treated with a combination of surgery and corticosteroids administered perioperatively.
\end{abstract}

Keywords: Kimura disease, parotid, surgery, steroid

öz

Kimura hastalığı (KH), Asyalı erkeklerde, etiyolojisi bilinmeyen nadir görülen kronik benign inflamatuar bir hastalıktır. Baş ve boyun bölgesi, özellikle parotid bezleri ve servikal lenf dügüüleri en sık etkilenen bölgelerdir. Tanı klinikopatolojik özelliklere dayanırken, radyoloji bulguları spesifik değildir. Çeşitli tedavi stratejileri önerilmiş olmakla birlikte, yüksek bir nüks oranı vardır. Kombinasyon tedavisi monoterapiden daha iyi sonuçlar vermektedir. Cerrahi ve perioperatif olarak uygulanan kortikosteroidlerin bir kombinasyonu ile tedavi edilen büyük parotid ve servikal lenf nodu tutulumu olan bir KH olgusunu sunuyoruz.

Anahtar kelimeler: Kimura hastalığı, parotid, cerrahi, steroid
Received: 24 April 2020

Accepted: 18 May 2020

Online First: 30 June 2020

Corresponding Author: I. Mohamad

ORCID: 0000-0001-8572-0514 Universiti Sains Malaysia Health

Campus, School of Medical Sciences, Department of Otorhinolaryngology-Head and Neck Surgery, Kelantan, Malaysia irfankb@usm.my

V.S.K. Eh Dam ORCID: 0000-0003-4802-2260

S. Mohamad ORCID: 0000-0002-4388-5350 Universiti Sains Malaysia Health

Campus, School of Medical Sciences, Department of Otorhinolaryngology-Head and Neck Surgery, Kelantan, Malaysia 


\section{INTRODUCTION}

Kimura disease (KD) is a rare chronic inflammatory disorder of unknown cause. It is characterized by subcutaneous lesions that mainly affect the head and neck region ${ }^{1}$. The exact prevalence of $\mathrm{KD}$ is not known; however, since its histopathological diagnosis was ascertained, only 200 cases have been reported ${ }^{2,3}$. The disease was first described in 1937 in China and has become widely known as KD after Kimura et al. published a definitive histologic description in $1948^{4}$. KD is prevalent in Asian males during their second-to-fourth decades of life, with some sporadic cases having been reported in Europe and America. The maleto-female ratio ranges from 3.5:1 to 6.7:11.

The parotid gland is the most common salivary gland involved in $\mathrm{KD}^{1,5,6}$, although its reason is unknown. Nevertheless, a clinicopathologic study of KD involving 21 parotid glands did not show parotid gland as its primary origin but revealed that pathological changes in the gland result from the spread of the disease from the intraparotid lymph nodes (LN) or adjacent soft tissues ${ }^{6}$. KD can be systemic and may involve multiple organs. Renal involvement is also a well-recognized manifestation that can present simultaneously or months to years later ${ }^{1}$.

\section{CASE REPORT}

A 16-year-old Malay boy presented with painless right infra-auricular swelling he had had for five years. The swelling had been slowly increasing in size; however, it had become rapidly enlarged over the previous six months and had extended to involve the pre-auricular and post-auricular regions. There were no associated obstructive, constitutional, ear or nasal symptoms, facial weakness or swelling elsewhere in the body. The patient was a non-smoker and denied any family history of malignancy.

He sought medical attention because the mass was causing facial disfigurement. Examination showed the presence of right parotid swelling, measuring $13 \mathrm{~cm} \times 13 \mathrm{~cm}$, extending from the zygomatic region superiorly to the submandibular region inferiorly and from the cheek region anteriorly to the post-auricular region posteriorly (Figure 1). The swelling was firm, non-tender with hyperpigmentation of the overlying skin. Multiple LNs were palpable at the right levels II and V. Other examinations were unremarkable.

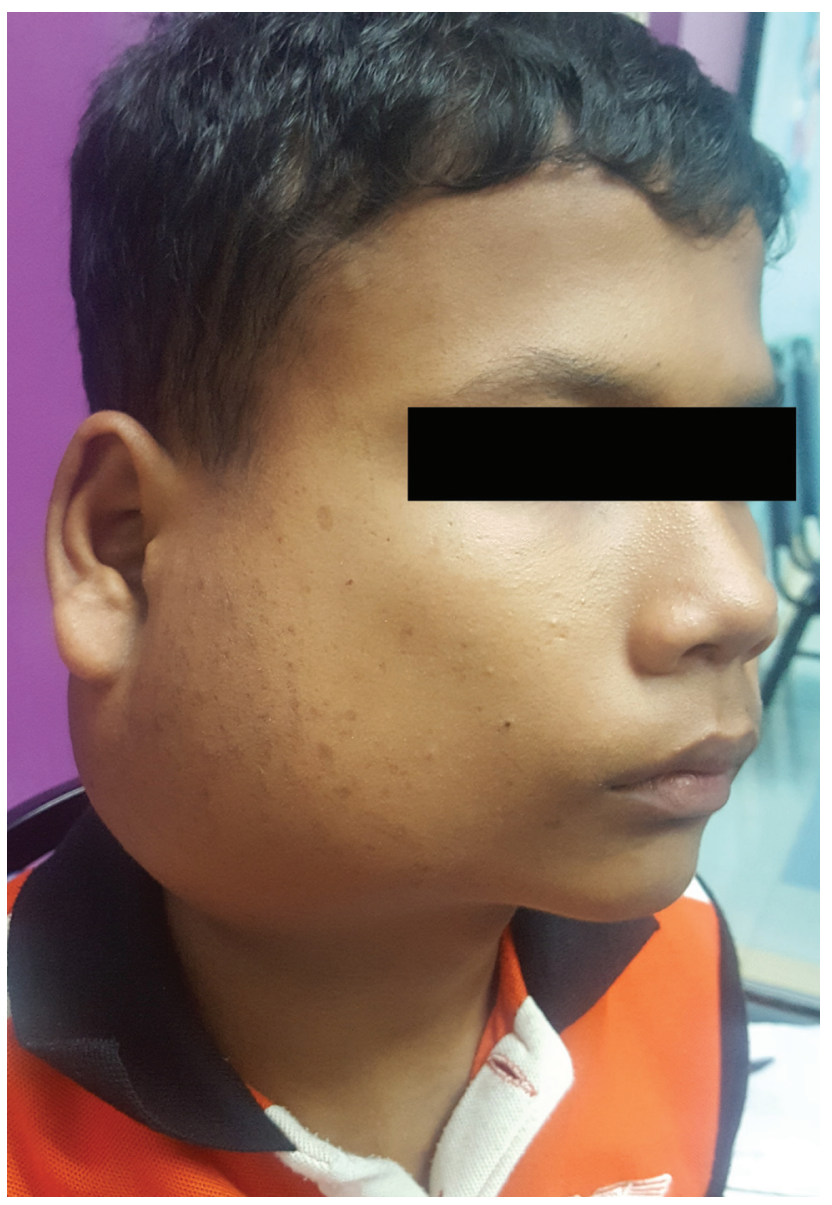

Figure 1. A huge swelling at right parotid region lesion measuring $13 \mathrm{~cm} \times 13 \mathrm{~cm}$ with hyperpigmented skin.

Reactive lymphadenitis with cellular atypia was diagnosed through fine needle aspiration cytology (FNAC), and KD was later confirmed with an incisional biopsy. A computed tomography (CT) scan of the neck revealed a large, ill-defined heterogenous enhancing soft tissue mass at a right angle to the mandible, measuring $7.6 \mathrm{~cm} \times 5.0$ 
$\mathrm{cm} \times 8.7 \mathrm{~cm}$, involving the right parotid gland and also the presence of multiple enlarged right cervical LNs from levels I to V (Figure 2).

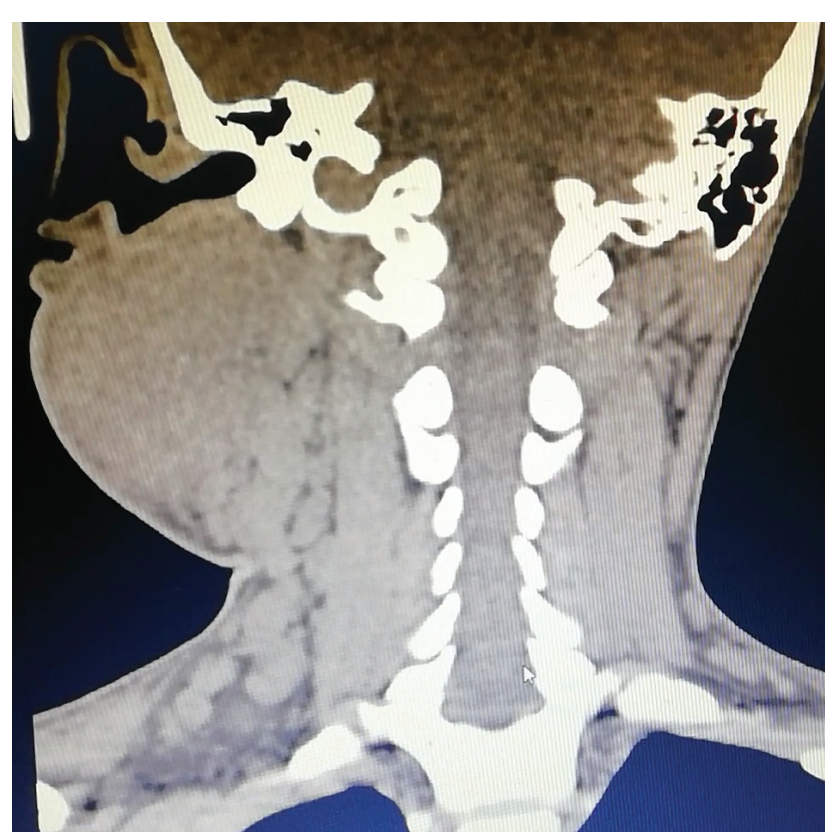

Figure 2. CT neck showed ill-defined large heterogenous enhancing soft tissue mass at right parotid mass measuring $7.6 \mathrm{~cm} \times 5.0 \mathrm{~cm} \times 8.7 \mathrm{~cm}$, with multiple enlarged right cervical LN.

Complete blood count showed leukocytosis with eosinophilia. The renal profile was normal. In view of the poor plane of the mass with surrounding structures, magnetic resonance imaging (MRI) of the neck was performed and showed enlargement of the right parotid, involving both superficial and deep lobes, measuring $8.4 \mathrm{~cm} \mathrm{x} 4.4 \mathrm{~cm} \mathrm{x}$ $8.9 \mathrm{~cm}$, with subcutaneous infiltration, and lack of any clear demarcation with the masseter muscle anteriorly and the sternocleidomastoid muscle posteriorly (Figure 3).

The patient was started on prednisolone oral tablets at daily doses of $30 \mathrm{mg}$ which were tapered every two weeks for two months as $25 \mathrm{mg}, 20$ $\mathrm{mg}$ and $15 \mathrm{mg}$, then maintenance daily dose of $10 \mathrm{mg}$ was continued for one year. The swelling reduced about 50\% from its initial size, and he was advised to have a right superficial parotidectomy.

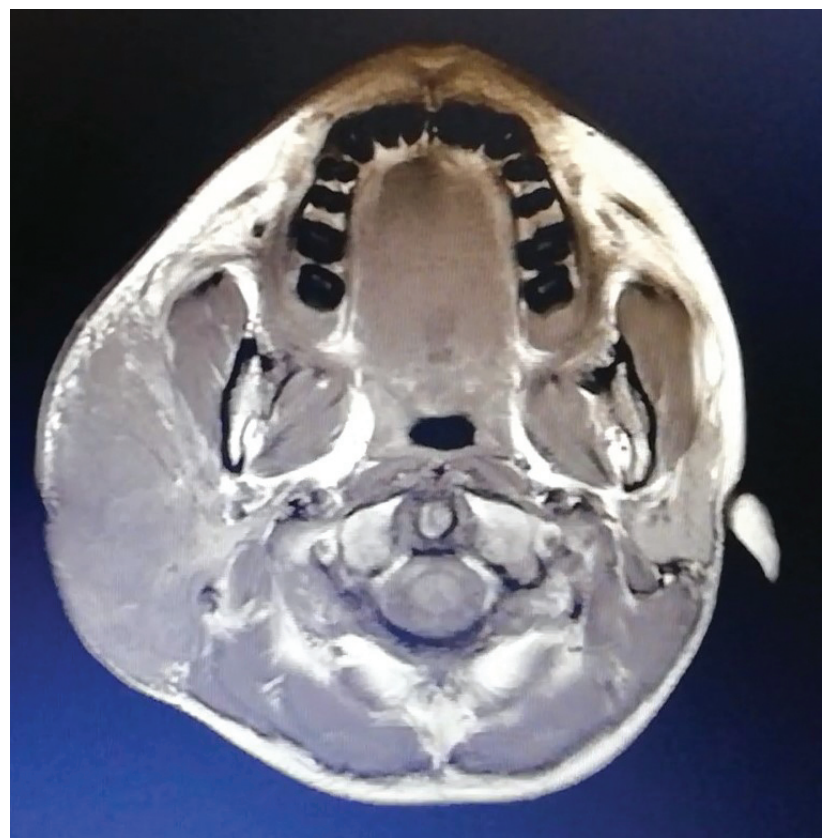

Figure 3. MRI neck T1-weighted axial view showed right parotid enlargement involving superficial and deep lobes measuring $8.4 \mathrm{~cm} \times 4.4 \mathrm{~cm} \times 8.9 \mathrm{~cm}$ with subcutaneous infiltration, and no clear demarcation with masseter and sternocleidomastoid muscles.

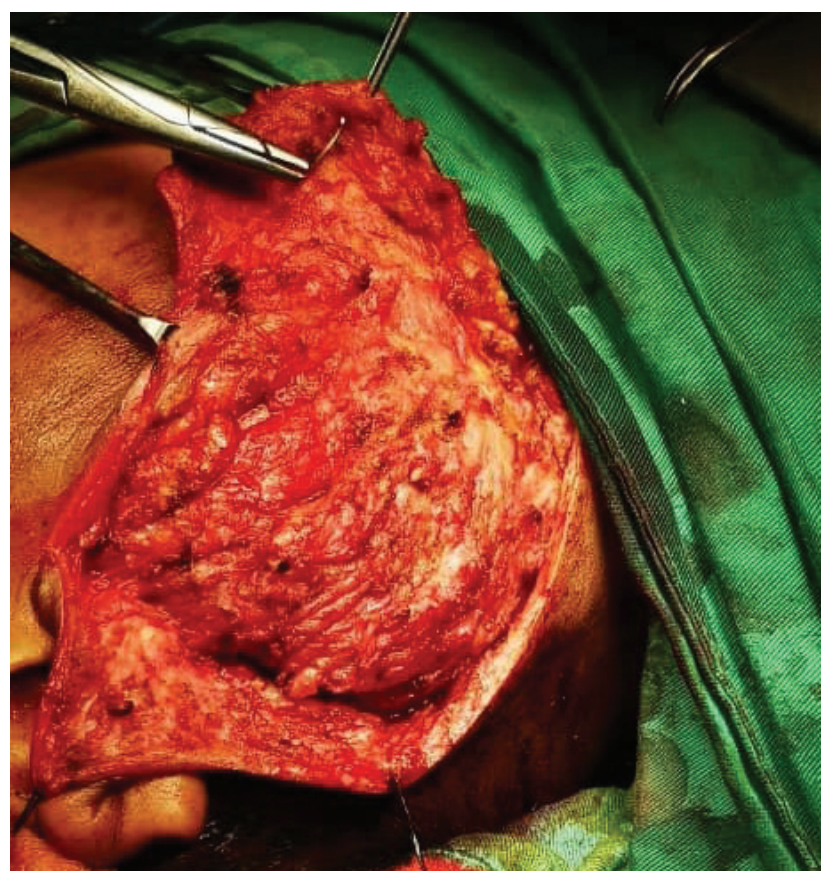

Figure 4. Intra-operative view, large right parotid mass with surrounding tissue fibrosis.

The presence of a large parotid gland with surrounding tissue fibrosis was found intraoperatively (Figure 4), and the superficial part of the parotid 
gland could be removed with preservation of the facial nerve. The patient was discharged on day three after the operation and the maintenance dose of prednisolone was continued. The wound was cleaned leaving a minimally edematous area at the right parotid region observed after one week (Figure 5). Histopathological examination (HPE) of the parotid gland was consistent with KD. The facial nerve was intact postoperatively.

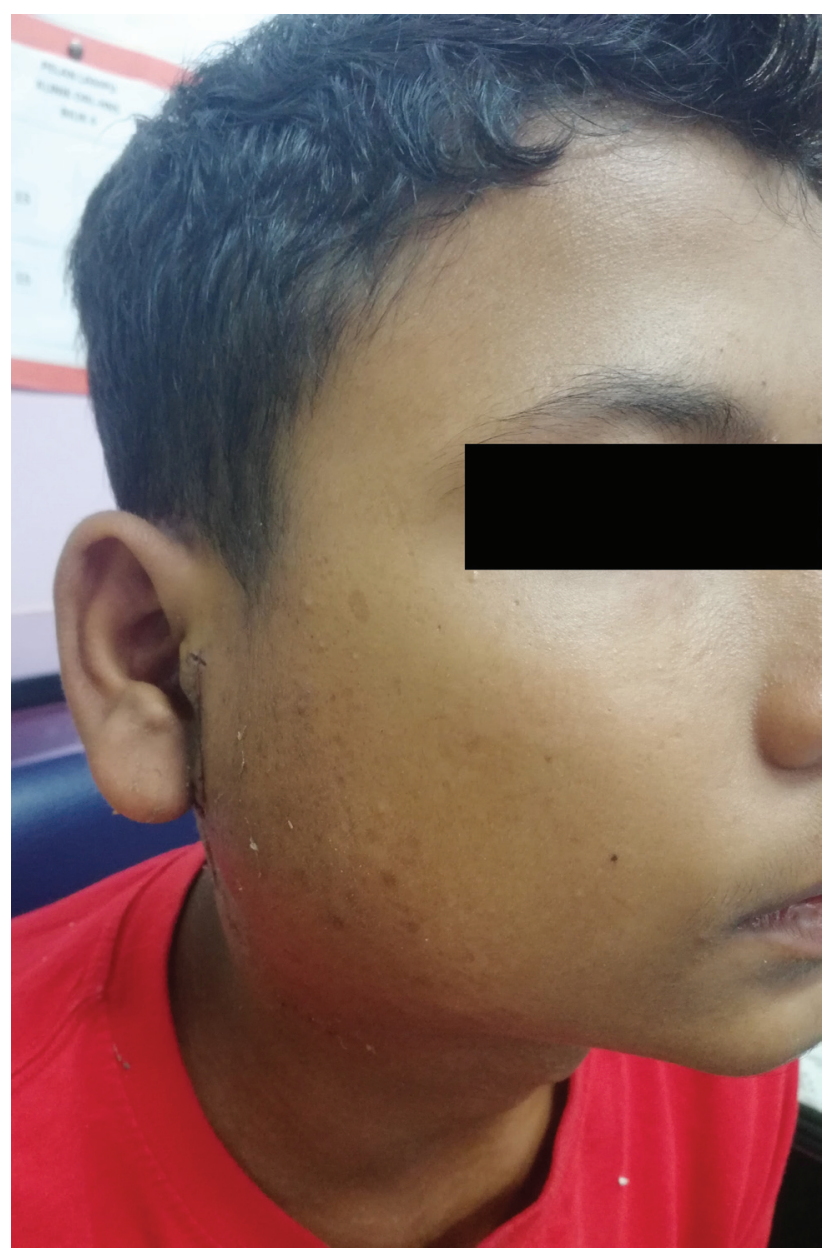

Figure 5. One week after operation, minimal edema edematous at right parotid region.

\section{DISCUSSION}

$K D$ is a benign inflammatory disease that may mimic other inflammatory and neoplastic conditions such as angiolymphoid hyperplasia with eosinophilia (ALHE), Hodgkin lymphoma, angioimmunoblastic T-cell lymphoma, allergic granuloma,
Langerhans cell histiocytosis, Castleman disease and immunoglobulin G4-related disease (IgG4$\mathrm{RD})^{1}$. There is no reported evidence of malignant transformation?

The diagnosis of KD is based on clinicopathological features, although there is no histologically pathognomonic feature ${ }^{1}$. It may be difficult to make a diagnosis of KD through routine initial investigations such as FNAC because limited amounts of tissue are obtained for examination. The finding of FNAC in our case was not specific to KD. Therefore, an incisional biopsy was performed which showed fragments of fibrocollagenous tissue that was heavily infiltrated by mature lymphocytes with the formation of multiple germinal centres and prominent mature eosinophils with occasional eosinophilic abscess. There were also scattered thick wall blood vessels; however, no hypertrophic endothelial cells or evidence of malignancy was observed. HPE of the parotid gland that was conducted during the operation revealed similar features. Infiltration of significant amounts of lymphocytes and eosinophils either in the tissue biopsy or, as in our case, in the blood serum are typical for KD and consistent with other studies ${ }^{7}$. However, the challenge in this case was the large size of the lesion, the poor surgical plane in relation to surrounding structures, especially the facial nerve and vessels, and the infiltration of the lesion into subcutaneous tissue through a very thin skin. Because of these factors, surgery was not the first treatment of choice; however, oral prednisolone was prescribed preoperatively to try to reduce the size and vascularity of the lesion.

Even though imaging modalities as ultrasound, CT scans or MRIs are non-diagnostic, the presence of multiple ill-defined enhancing masses within and around the parotid gland with associated regional lymphadenopathy that are seen in CT scans or MRIs are suggestive of $\mathrm{KD}^{8}$. The disease can be divided into two types based on CT scan features, type 1 being well-defined, enhancing, homogeneous masses with clear boundaries and intact 
capsules and type 2 being ill-defined, heterogeneous masses with variable enhancement, unclear boundaries, and without obvious capsules ${ }^{9}$. It is uncertain whether these types are two distinct entities or if there a potential disease progression from type 1 to type 2 in long standing disease. In terms of management, surgery alone may not be the first choice of treatment in type $2 \mathrm{KD}$, as there is no clear boundary or intact capsule and therefore a possible higher recurrence rate. As our patient was diagnosed with type 2 based on radiological examination, we opted for the combined modality of corticosteroids and superficial parotidectomy.

Numerous treatment modalities have been reported, but because of the rarity of KD most of the clinical studies are case reports or series ${ }^{10}$. Therefore, the optimal treatment is still uncertain considering the high recurrence rate ${ }^{1}$. Surgical excision, radiotherapy, systemic corticosteroids, cytotoxic agents, cyclosporin, pentoxifylline, leflunomide, mycophenolate mofetil, and imatinib are among the treatments that have been reported and shown variable responses ${ }^{8,11}$. The dosages and durations of medical treatments either for curative intent or as neoadjuvants or adjuvants to surgery differ widely across the literature. Oral prednisolone was highly individualized and administered at a variety of dosages (10-60 $\mathrm{mg} /$ day), durations, and tapering schedules depending on the sizes of the primary or recurrent lesions ${ }^{12,13}$.

\section{CONCLUSION}

$\mathrm{KD}$ is a rare benign disease with possible systemic involvement and a high recurrence rate. To date, the definitive treatment remains uncertain; therefore, we suggest that the treatment should be highly individualized. Since the head and neck re- gion is most commonly affected and because the disease is complex in nature, decisions regarding the management should be made cautiously by multidisciplinary teams. A combination of corticosteroids and parotidectomy is a possible treatment of choice for KD with parotid and cervical lymph node involvement.

\section{REFERENCES}

1. Zhang X, Jiao Y. The clinicopathological characteristics of Kimura disease in Chinese patients. Clin Rheumatol. 2019;38:3661-7. [CrossRef]

2. Bonfils P, Moya-Plana A, Badoual C, Nadéri S, Malinvaud D, Laccourreye O. Intraparotid Kimura disease. Eur Ann Otorhinolaryngol Head Neck Dis. 2013;130:87-9. [CrossRef]

3. Dhingra H, Nagpal R, Baliyan A, Alva SR. Kimura disease: case report and brief review of literature. Med Pharm Rep. 2019;92(2):195-9. [CrossRef]

4. Li TJ, Chen XM, Wang SZ, Fan MW, Semba I, Kitano M. Kimura's disease: a clinicopathologic study of 54 Chinese patients. Oral Surg Oral Med Oral Pathol Oral Radiol Endod. 1996;82:549-55. [CrossRef]

5. Chen H, Thompson LD, Aguilera NS, Abbondanzo SL. Kimura disease: a clinicopathologic study of 21 cases. Am J Surg Pathol. 2004; 28:505-13. [CrossRef]

6. Gao Y, Chen Y, Yu GY. Clinicopathologic study of parotid involvement in 21 cases of eosinophilic hyperplastic lymphogranuloma (Kimura's disease). Oral Surg Oral Med Oral Pathol Oral Radiol Endod. 2006;102:651-8. [CrossRef]

7. Sun QF, Xu DZ, Pan SH, et al. Kimura disease: Review of the literature. Intern Med J. 2008;38:668-72. [CrossRef]

8. Park SW, Kim HJ, Sung KJ, Lee JH, Park IS. Kimura disease: $\mathrm{CT}$ and MR imaging findings. AJNR Am J Neuroradiol. 2012;33:784-8. [CrossRef]

9. Gopinathan A, Tan TY. Kimura's disease: Imaging patterns on computed tomography. Clin Radiol. 2009;64:994-9. [CrossRef]

10. Ye P, Wei T, Yu GY, Wu LL, Peng X. Comparison of local recurrence rate of three treatment modalities for Kimura disease. J Craniofac Surg. 2016;27:170-4. [CrossRef]

11. Shah K, Tran AN, Magro CM, Zang JB. Treatment of Kimura disease with mycophenolate mofetil monotherapy. JAAD Case Rep. 2017;3:416-9. [CrossRef]

12. Chang AR, Kim K, Kim HJ, Kim IH, Park CI, Jun YK. Outcomes of Kimura's disease after radiotherapy or nonradiotherapeutic treatment modalities. Int J Radiat Oncol Biol Phys. 2006;65:1233-9. [CrossRef]

13. Chen QL, Dwa S, Gong ZC, et al. Kimura's disease: risk factors of recurrence and prognosis. Int J Clin Exp Med. 2015;8:21414-20. 